\title{
Exercise-induced anaphylaxis: A clinical view
}

\author{
Carlotta Povesi Dascola and Carlo Caffarelli ${ }^{*}$
}

\begin{abstract}
Exercise-induced anaphylaxis (EIA) is a distinct form of physical allergy. The development of anaphylaxis during exertion often requires the concomitant exposure to triggering factors such as intake of foods (food dependent exercise-induced anaphylaxis) or drugs prior to exercise, extreme environmental conditions. ElA is a rare, but serious disorder, which is often undetected or inadequately treated. This article summarizes current evidences on pathophysiology, diagnosis and management. We reviewed recent advances in factors triggering the release of mediators from mast cells which seems to play a pathogenetic role. A correct diagnosis is essential to avoid unnecessary restricted diet, to allow physical activity in subjects with EIA dependent from triggering factors such as food, and to manage attacks. An algorithm for diagnosing EIA based on medical history, lgE tests and exercise challenge test has been provided. In the long-term management of EIA, there is a need for educating patients and care-givers to avoid exposure to precipitating factors and to recognize and treat episodes. Future researches on existing questions are discussed.
\end{abstract}

Keywords: Physical exercise, Food allergy, Exercise-induced anaphylaxis, Exercise-induced bronchocostriction, Urticaria, Anaphylaxis

\section{Introduction}

Physical exercise may provoke the onset of clinical symptoms that are usually due to an allergic reaction. Distinct forms of recognized physical allergies are exercise-induced anaphylaxis (EIA), cholinergic urticaria, exercise-induced bronchospasm and rhinitis.

Anaphylaxis triggered by physical exertion is a serious disorder which is often undetected or inadequately treated. EIA is rare, with a prevalence of $0.048 \%$ in a survey of 76.229 adolescents, aged 13-15 years [1]. Up to $9 \%$ of children referred to a tertiary allergy center for anaphylaxis suffer from EIA [2]. EIA affects subjects at any time during lifespan and age of onset varies from 4 to 74 years $[3,4]$. Concomitant factors may be required to develop anaphylaxis during exertion. In 30\% [1] - 50\% of cases [3], EIA occurs only when the subject ingests a particular food before exercise, known as specific food dependent exercise-induced anaphylaxis (FDEIA) [5] or a meal (non-specific FDEIA) prior to exercise [6]. Angioedema and oral allergy syndrome have been reported in an 8 years-old boy who ingested tomatoes

\footnotetext{
* Correspondence: carlo.caffarelli@unipr.it

Clinica Pediatrica, Dipartimento di Medicina Clinica e Sperimentale, Azienda Ospedaliera-Universitaria di Parma, Università degli Studi di Parma, Via Gramsci 14, Parma, Italy
}

after physical exercise [7]. Exercise or food alone do not elicit symptoms. Maulitz et al. [5] described the first case of shellfish dependent EIA in 1979. Afterwards, many different types of foods have been reported to predispose the development of EIA. They include celery [8], wheat [9-11], shellfish [12], grapes [11], nuts [13], peaches [13], eggs [14,15], oranges [16], apples [17], hazelnuts [18], chees [19], cabbage [3], chestnuts [20], rice [20], tomatoes [20], cuttlefish [21], pistachios [22], cow's milk [23], corn, paprika, mustard, barley [24], onions [25], peanuts [15,26], fish [27], snails [28], pork [29], beef [29], chicken/turkey [30], mushrooms [31], buckwheat [32], alcohol [3]. Some patients are sensitive to more than one type of food [20]. In some patients with FDEIA, aspirin intake [33], cold [34] or warm environment [35] are required for developing the reaction. FDEIA may occur only when two types of foods are simultaneously ingested before exercise [29,36]. Moreover, during cow's milk desensitization, children may have cow's milk dependent EIA episodes [37]. In many patients with EIA, food intake is not related to EIA occurrence but other precipitating factors have been reported. They are drugs $[3,5,8,38]$, cold or warm temperature, humidity [3,38-40], menstrual cycle [11], dental amalgam [40], pollen season [3], ingestion of dust mites contained in 
contaminated foods [41]. A family history of EIA has been associated with the HLA A3B8DR3 [42] or with a possible autosomal dominant inheritance [43]. Subjects with EIA or FDEIA [44] are often atopic. These findings might suggest a potential genetic origin for EIA.

\section{Pathophysiology}

In EIA, the release of vasoactive mediators from mast cells may play a pathogenetic role. This has been observed in skin biopsies [45] and it has been confirmed by findings of increased serum histamine [45-47] and tryptase [48] levels in patients with EIA after exercise. Release of mast cell mediators may result in vascular leakage, inflammatory cell recruitment and occurrence of anaphylaxis [49]. The mast cell degranulation may be mediated by IgE antibodies. However, in patients with EIA, serum IgE antibodies are usually normal in patients who do not suffer from allergic diseases [50]. Other triggering factors may be lactate or creatinine phosphokinase [51]. Overall, it remains unclear which factors trigger mast cell degranulation. In patients with FDEIA, the ingestion of the offending food alone does not provoke clinical hypersensitivity reactions, even if IgE antibodies against the causative food allergens are usually detected by skin prick tests or in the serum. Non mutually exclusive explanations have been provided for the loss of tolerance to food during exercise [52]. Some of them are sustained by clinical findings. First, the administration of sodium bicarbonate before physical activity prevents occurrence of symptoms in patients with FDEIA [53]. Therefore it has been suggested that $\mathrm{pH}$ modifications might elicit the onset of anaphylaxis. Along this line, it has been reported that after physical activity, $\mathrm{pH}$ decreases both in serum and in muscle [54,55]. Furthermore, a reduced $\mathrm{pH}$ enhances mast cell degranulation [56]. Second, aspirin appears to induce anaphylactic reaction to wheat by increasing gastrointestinal permeability. This is suggested by the fact that in patients with wheat dependent EIA, both wheat-exercise and wheat-aspirin challenges provoked an increased gliadin absorption and allergic symptoms. Higher serum gliadin levels may cause degranulation of mast cell with onset of anaphylaxis [57]. Small intestinal permeability is increased by exercise [58]. However, it has been shown that serum gladin levels are similarly increased during combination wheat-exercise test in subjects with FDEIA and in controls [56], ruling out a role for increased gastrointestinal permeability.

Further hypotheses have been offered. Mucosal mast cells and connective tissue mast cells differ in release of histamine and leukotrienes $[59,60]$. Exposure to allergenic foods of gut-specific mast cells seems to lead to tolerate the food. During exercise, there is a redistribution of blood flow from the gut to skin or skeletal muscle where mast cells may be more responsive to the causative food. Consequently, a greater exposure of the connective tissue mast cells to allergenic foods may result in an increased release of mediators and development of EIA [52]. Another explanation has been provided for wheat dependent EIA. Tissue transglutaminase (tTG) are activated by IL- 6 produced by skeletal muscle in response to exercise. Pepsin digestion of wheat allergens including omega- 5 gliadin, the main wheat allergen in FDEIA [61], forms peptides that are cross-linked by tTG into high-molecular-weight complexes which strongly bind to IgE. It has been suggested that these allergen complexes may elicit anaphylactic reactions in patients with wheat dependent EIA [62].

The autonomic system may also play a role in FDEIA since an increased activity of the parasympathetic nervous system and a reduced activity of the sympathetic nervous system have been reported [14]. Lastly, an increased histamine release from basophils of FDEIA patients has been found at elevated osmolality levels $[63,64]$. Therefore, serum hyperosmolality might increase basophil releasability after food allergen intake [65]. However, such osmolality levels are not reached in plasma during physical activity [64].

\section{Clinical presentation}

EIA has been associated with both strenuous and mild, especially in children, physical activities [66]. The intensity of the exercise and amount of food ingested may provoke different symptoms from subject to subject and in the same subject $[66,67]$. Any kind of exercise may potentially induce the reaction. Walking, jogging, running, aerobics, dancing, swimming, cycling, horse riding, tennis, basketball, soccer, skiing, raking leaves have been reported $[3,68,69]$. Symptoms may appear during warmup, maintenance or cool-down phases. Patients do not always experience symptoms every time they practice physical activity.

The reaction often occurs within $30 \mathrm{~min}$ from the onset of physical exertion. However, Oyefaras BL et al. [70] described a patient who developed wheatdependent EIA, $5 \mathrm{~h}$ after exercise. EIA symptoms may be serious and fatalities have been sporadically reported in adults $[32,71,72]$. Symptoms of EIA are similar to those of anaphylactic reactions caused by allergens such as foods or hymenoptera venom. In the beginning, children commonly present pruritus or tingling in the extremities followed by generalized pruritus and warmth, urticaria-angioedema and flushing. Among respiratory symptoms, cough, chest thightness, wheezing with impaired spirometric values [73] appear in about $50 \%$ of cases while rhinitis, hoarseness and laryngeal dyspnea are less frequent [44]. In $25-30 \%$ of cases, sweating, gastrointestinal complaints (frequently vomiting), 
headache, faintness, collapse and syncope, may occur [44]. Some patients experience late symptoms which occur after 24-48 h (biphasic anaphylaxis). Natural history of EIA is not well known. A reduction in the number of attacks with time has been reported [69], but recovery is unlikely.

\section{Diagnosis}

A correct diagnosis is essential to avoid unnecessary restricted diet, to allow physical activity in subjects with EIA dependent from triggering factors such as food, and to manage attacks. Careful medical history is critical to identify the events that precipitate the reaction and involved cofactors. Generally, history of food reactions is unreliable [74]. Also in FDEIA, history may only suggest foods whose intake is a prerequisite for the development of the reaction [75]. Skin prick tests and/or circulating IgE antibodies for all foods ingested before physical activity are helpful for identifying the offending food. In our experience, in specific FDEIA, IgE test results were positive for the causative food, while non-specific FDEIA or in EIA, IgE test were negative.

Open challenge test is the definitive mean to ascertain the diagnosis and it is required when medical history and IgE test results are unclear or discordant (Figure 1). The challenge test should be performed under medical supervision with accessibility to equipment and support for managing anaphylactic reactions. When symptoms develop, blood pressure should be monitored [76] and treatment promptly given. In children, the exercise challenge test may consist in performing an exertion continuously for at least $6 \mathrm{~min}$ to reach $80 \%$ of maximum heart frequency predicted for age, following the protocol for exercise-induced broncocostriction [20,73,75,77]. In children, free running is preferred to tapis roulant or cycle ergometer because it is more easily accepted and performed. Lung function should be measured at baseline, at the end of exercise and then every 3 min for 3 times [73]. The exercise challenge in adults is usually performed according to the protocol for ischemic heart disease $[78,79]$. Exercise test is performed on fasting to identify subjects with EIA. When it is negative, after successful elimination of suspected foods, a combination food-exercise challenge test is required. Food challenge alone is rarely necessary. The exercise test should be performed $1 \mathrm{~h}$ after the ingestion of each of the suspected foods to ascertain specific FDEIA and $1 \mathrm{~h}$ after a meal to diagnose non-specific FDEIA. The combined food-exercise test can usually identify the triggering foods. However, a negative exercise challenge test does not exclude the diagnosis of EIA since it is negative in about $30 \%$ of cases $[11,80]$. This is partly explained by the fact that in some cases the exposure to triggering factors such extreme environments $[34,35]$ are necessary to elicit the reaction and they cannot be reproduced in the laboratory. A double-blind placebo controlled combined food-exercise test may be required when symptoms are unusual or ambiguous [81].

The differential diagnosis of childhood EIA with other allergies induced by exertion is challenging. Cholinergic urticaria occurs with small wheals (diameter $2-4 \mathrm{~mm}$ ) and a large erythema. These lesions frequently arise in the upper part of the chest and subsequently spread to the whole body [82]. A single lesion often resolves in 15-20 min, even if the episode may last $2-4 \mathrm{~h}$. This type of urticaria is triggered by the rise in core body temperature and it is due

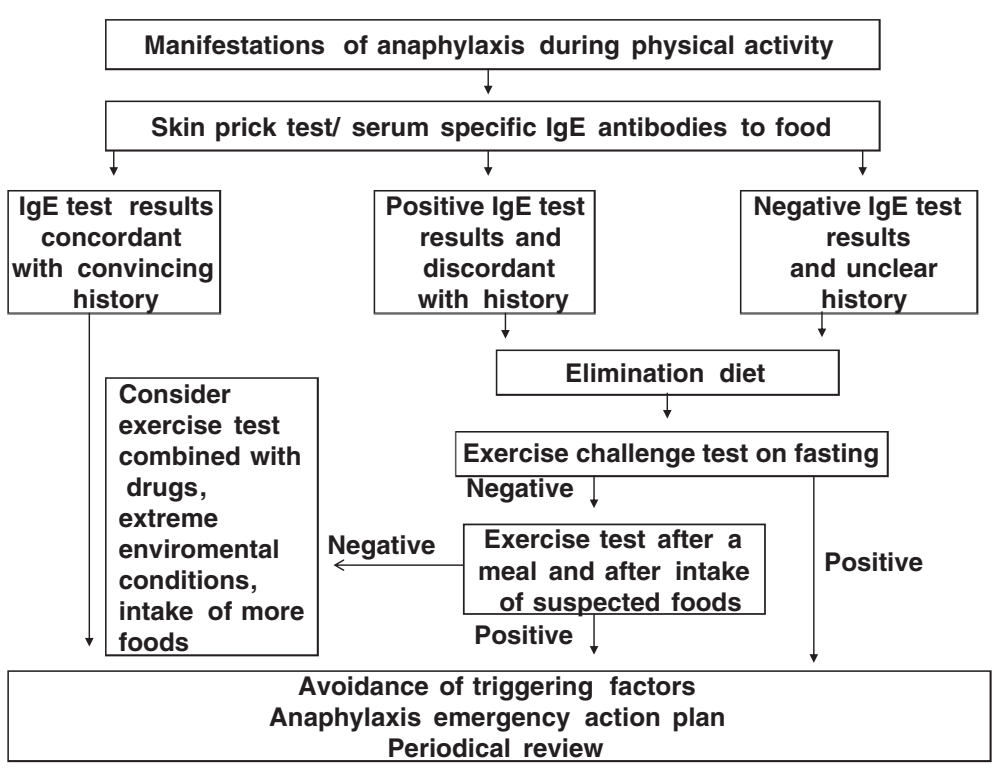

Figure 1 Diagnosis of EIA. 
to both active mechanisms (exercise, stress, fever) and passive (hot shower). Manifestations of EIA (bronchospasm, angioedema, hypotension) may appear in patients with cholinergic urticaria. In these cases, cholinergic urticaria is easily differentiated from EIA, since symptoms are induced not only by physical exertion but also by an increase in body temperature.

Exercise-induced bronchoconstriction is characterized by asthma symptoms or cough [83] that usually occur within 10-15 min after physical activity, rarely during exercise. Symptoms resolve in a variable time within an hour after the end of the exercise. Exercise-induced bronchoconstriction is experienced by most asthmatic children and is not associated with anaphylactic symptoms or food intake. The diagnostic value of medical history [84] in identifying individuals suffering from exercise-induced bronchoconstriction is poor. Hallstrand et al. [85] found that $12 \%$ of children with a history of exercise-induced bronchoconstriction and $8.7 \%$ of those without history had positive exercise test results. Therefore, the diagnosis of exercise-induced bronchoconstriction should be based on exercise challenge test results. [85]. A positive exercise test is defined as a maximum percentage fall in FEV1 $\geq 15 \%$ from the baseline [77]. Exercise test may be influenced by the type of exercise, environmental conditions, hour of the day, and the health of the child (infections, allergies, drugs).

The following disorders also need to be considered as alternative diagnosis when symptoms occur during exercise: hyperventilation syndrome, panic or vasovagal attacks, vocal cord dysfunction. Hereditary angioedema attacks may occasionally be associated with exercise but they are not caused by food intake and occur also at rest. In cardiac diseases or in neurologic disorders, collapse may occur during physical activity but are not associated with anaphylactic symptoms. Patients with cold-urticaria may develop symptoms of EIA when they practice exercise in a cold environment. Non exercise-dependent food allergy is excluded by a negative IgE test results to a previously tolerated food. In some instances, oral food challenge test is necessary.

\section{Management}

Patients with EIA and their families should be educated to prevent further attacks by avoiding relevant triggers. In children with FDEIA, physical activity is permitted only after at least $4 \mathrm{~h}$ from the ingestion of the culprit food [1]. The food should be avoided also for $1 \mathrm{~h}$ after exercise [29]. Participation of children with FDEIA in physical activity should be encouraged since it has a positive effect on their physical and social well-being. It has been sporadically reported that some patients respond to prophylactic treatment [46] with sodium cromoglycate [86,87], H2-antihistamines [87-89], leukotriene modifiers
[89], steroids [36] or sodium bicarbonate [53]. However, there is not sufficient evidence to routinely recommend preventive drugs. Another point is that patients and caregivers should be instructed to recognize and treat episodes since parents are often unable to schedule exertion in children. A personalized, written anaphylaxis emergency action plan should be given. Patients or care-givers must always keep self-injectable epinephrine available and should be educated on how to use it. Every year, the action plan as well as the practical use of epinephrine should be reviewed. All at-risk patients should never exercise alone, but always with a person who has been trained in treating anaphylactic reactions. Patients should be able to recognize prodromal symptoms and anaphylactic manifestations. At the first occurrence of symptoms, exertion should be terminated. The subject should be put in the supine position [90] and self-injectable epinephrine followed by $\mathrm{H} 2-$ antihistamines and steroids should be promptly administered. The supine patient should be quickly transported to the hospital.

\section{Conclusions}

EIA represents a growing recognized worldwide health problem. Further studies are necessary to elucidate many existing questions. Hypotheses on EIA pathophysiology should be sustained by clinical observations. Method for exercise challenge test that is considered the goldstandard for diagnosing EIA, needs to be standardized. Finally, if the subjects who benefit from preventive treatment are identified, significant improvement in the health and quality of life of patients with EIA and their families are likely.

\section{Abbreviations}

EIA: Exercise-induced anaphylaxis; FDEIA: Food dependent exercise-induced anaphylaxis.

\section{Competing interests}

The authors declare that they have no competing interests.

\section{Authors' contribution}

All authors declare to have equally contributed to choose the subject, writing of the paper, and reviewing the literature data. Both authors read and approved the final manuscript.

Received: 6 September 2012 Accepted: 11 September 2012

Published: 14 September 2012

\section{References}

1. Aihara Y, Takahashi $Y$, Kotoyori T, Mitsuda T, Ito R, Aihara M, Ikezawa Z, Yokota S: Frequency of food-dependent, exercise-induced anaphylaxis in Japanese junior-high-school students. J Allergy Clin Immunol 2001, 108:1035-1039.

2. Novembre E, Cianferoni A, Bernardini R, Mugnaini L, Caffarelli C, Cavagni G, Giovane A, Vierucci A: Anaphylaxis in children: clinical and allergologic features. Pediatrics 1998, 101(4):E8.

3. Wade JD, Liang MH, Sheffer AL: Exercise-induced anaphylaxis: epidemiologic observations. In Progress in clinical and biological research: biochemistry of acute allergic reactions. Edited by Tauber AL, Wintrob BU, Stolper-Simon AS. New York: Alan R Liss; 1989:175-182. 
4. Lashley M, Klein N: Case report: exercise-induced anaphylaxis. Ann Allergy 1990, 64:381-382.

5. Maulitz RM, Pratt DS, Schocket AL: Exercise induced anaphylactic reaction to shellfish. J Allergy Clin Immunol 1979, 63:433-434.

6. Novey HS, Fairshter RD, Salness K, Simon RA, Curd JG: Post-prandial exercise-induced anaphylaxis. J Allergy Clin Immunol 1983, 71:498-504.

7. Caffarelli C, Zinelli C, Petroccione C, Bernasconi S: Angioedema in a child due to eating tomatoes after exercise. Clin Exp Dermatol 2006, 31:294-295.

8. Kidd JM, Cohen SH, Fink JN: Food-dependent exercise-induced anaphylaxis. J Allergy Clin Immunol 1983, 71:407-411.

9. Aoki T, Kushimoto H: Masked type I wheat allergy. Arch Dermatol 1985, 121:355-360

10. Akutsu I, Motojima S, Ikeda Y, Fukuda T, Ikemori R, Makino S: Three cases of food-dependent exercise-induced anaphylaxis. Aerugi 1988, 38:277-284.

11. Dohi M, Suko M, Sugiyama H, Yamashita N, Takodoro K, Juji F, Okudaira H, Sano Y, Ito K, Miyamoto T: Food-dependent exercise-induced anaphylaxis: a study on 11 Japanese cases. J Allergy Clin Immunol 1991, 87:34-40.

12. McNeil D, Strauss R: Exercise-induced anaphylaxis related to food intake. Ann Allergy 1988, 61:440.

13. Buchbinder EM, Bloch KJ, Moss J, Guiney TE: Food dependent exerciseinduced anaphylaxis. JAMA 1983, 250:2973-2974.

14. Fukutomi O, Kondo N, Agata H, Shinoda S, Shinbara M, Orii T: Abnormal responses of the autonomic nervous system in food-dependent exercise-induced anaphylaxis. Ann Allergy 1992, 68:438-445.

15. Tewari A, Du Toit G, Lack G: The difficulties of diagnosing food dependent exercise-induced anaphylaxis in childhood - a case study and review. Pediatr Allergy Immunol 2006, 17:157-160.

16. Debavelaere C, De Blic J, Bodemer C, Teillac D, Paupe J, Scheinmann P: Syndrome d'anaphylaxie induite par l'exercice. Arch Fr Pediatr 1989, 46:281-283

17. Anibarro B, Dominguez C, Diaz JM, Martin MF, Garcia Ara MC: Appledependent exercise-induced anaphylaxis. Allergy 1994, 49:481-482.

18. Martin-Munoz F, Lopez Cazana JM, Villas F, Coutreras JF, Diaz JM, Ojeda JA: Exercise-induced anaphylactic reaction to hazelnut. Allergy 1994, 49:314-316.

19. Tiles $\mathrm{S}$, Shocket $\mathrm{A}$, Milgrom H: Exercise-induced anaphylaxis related to specific foods. J Pediatr 1995, 127:587-589.

20. Caffarelli C, Terzi V, Perrone F, Cavagni G: Food related, exercise induced anaphylaxis. Arch Dis Child 1996, 75:141-144.

21. Caffarelli $C$, Terzi $V$, Perrone F: Exercise-induced anaphylaxis related to cuttlefish intake. Eur J Pediatr 1996, 155:1025-1026.

22. Porcel S, Sanchez AB, Rodriguez E, Fletes C, Alvarado M, Jimenez S, Hernandez J: Food-dependent exercise-induced anaphylaxis to pistachio. J Investig Allergol Clin Immunol 2006, 16:71-73.

23. Garcia-Ara MC, Sanchez AV, Martinez MT, Díaz Pena JM: Cow's milkdependent, exercise-induced anaphylaxis: case report of a patient with previous allergy to cow's milk. J Allergy Clin Immunol 2003, 111:647-648.

24. Mathelier-Fusade P, Vermeulen C, Leynadier F: Responsibility of food in exercise-induced anaphylaxis: 7 cases. Ann Dermatol Venereol 2002, 129:694-697.

25. Perez-Calderon R, Gonzalo-Garijo MA, de Soria Fernandez R: Exerciseinduced anaphylaxis to onion. Allergy 2002, 57:752-753.

26. Romano A, Di Fonso M, Giuffreda F, Papa G, Artesani MC, Viola M, Venuti A Palmieri V, Zeppilli P: Food-dependent exercise-induced anaphylaxis: clinical and laboratory findings in 54 subjects. Int Arch Allergy Immuno 2001, 125:264-272

27. Kano H, Juji F, Shibuya N, Narita M, Naritaka S, Suko M, Morita Y, Iwata T: Clinical courses of 18 cases with food-dependent exercise- induced anaphylaxis. Arerugi 2000, 49:472-478.

28. Longo G, Barbi E, Puppin F: Exercise-induced anaphylaxis to snails. Allergy 2000, 55:513-514.

29. Biedermann T, Schopf $P$, Rueff F, Przybilla B: Exertion- induced anaphylaxis after eating pork and beef. Dtsch Med Wochenschr 1999, 124:456-458.

30. Asero R, Mistrello G, Roncarolo D, Antoniotti P, Falagiani P: Exerciseinduced egg anaphylaxis. Allergy 1997, 52:687-689.

31. Okano M, Sakuma Y: Food-dependent exercise-induced anaphylaxis due to matsutake mushrooms. Br J Dermatol 1997, 136:805.

32. Noma T, Yoshizawa I, Ogawa N, Ito M, Aoki K, Kawano Y: Fatal buckwheat dependent exercised-induced anaphylaxis. Asian Pac J Allergy Immunol 2001, 19:283-286.

33. Harada S, Horikawa T, Ashida M, Kamo T, Nishioka E, Ichihashi M: Aspirin enhances the induction of type I allergic symptoms when combined with food and exercise in patients with food-dependent exerciseinduced anaphylaxis. Br J Dermatol 2001, 145:336-339.

34. Shimizu T, Furumoto H, Kinoshita E, Ogasawara Y, Nakamura C, Hashimoto Y, Nagai K, Muto M: Food-dependent exercise-induced anaphylaxis occurring only in winter. Dermatology 2000, 200:279.

35. Jo EJ, Yang MS, Kim YJ, Kim HS, Kim MY, Kim SH, Cho SH, Min KU, Chang YS: Food-dependent exercise-induced anaphylaxis occurred only in a warm but not in a cold environment. Asia Pac Allergy 2012, 2:161-164.

36. Aihara Y, Kotoyori T, Takahashi Y, Osuna H, Ohnuma S, Ikezawa Z: The necessity for dual food intake to provoke food-dependent exerciseinduced anaphylaxis (FEIAn): a case report of FEIAn with simultaneous intake of wheat and umeboshi. I Allergy Clin Immunol 2001, 107:1100-1105.

37. Caminiti L, Passalacqua G, Vita D, Ruggeri P, Barberio G, Pajno GB: Food exercise- induced anaphylaxis in a boy successfully desensitized to cow milk. Allergy 2007, 62:335-336.

38. Sheffer AL, Austen KF: Exercise-induced anaphylaxis. J Allergy Clin Immunol 1984, 73:699-703.

39. Li M, Sayama K, Tohyama M, Hashimoto K: A case of cold-dependent exercise-induced anaphylaxis. Br J Dermatol 2002, 147:368-371.

40. Katsunuma T, likura Y, Nagakura T, Saitoh H, Akimoto K, Akasawa A, Kindaichi S: Exercise-induced anaphylaxis: improvement after removal of amalgam in dental caries. Ann Allergy 1990, 64:472-475.

41. Sanchez-Borges M, Iraola V, Fernandez-Caldas E, Capriles-Hulett A, CaballeroFonseca F: Dust mite ingestion-associated, exercise induced anaphylaxis. J Allergy Clin Immunol 2007, 120:714-715.

42. Longley S, Panush RS: Familial exercise-induced anaphylaxis. Ann Allergy 1987, 58:257-259.

43. Grant JA, Farnant J, Lord RA, Thueson DO, Lett-Brown MA, Wallfisch H, Fine DP, Schmalstieg FC: Familial exercise-induced anaphylaxis. Ann Allergy 1985, 54:35-38.

44. Tanaka S: An epidemiological survey on food dependent exerciseinduced anaphylaxis in kindergartners, schoolchildren and junior high school students. Asia Pac J Public Health 1994, 7:26-30

45. Sheffer AL, Tong AK, Murphy GK, Lewis RA, McFadden ER Jr, Austen KF: Exercise-induced anaphylaxis: a serious form of physical allergy associated with mast cell degranulation. J Allergy Clin Immunol 1985 75:479-484

46. Volcheck G, Li JT: Exercise-induced urticaria and anaphylaxis. Mayo Clin Proc 1997, 72(2):140-147.

47. Lewis J, Lieberman P, Treadwell G, Erffmeyer J: Exercise-induced urticaria angioedema and anaphylactoid episodes. J Allergy Clin Immunol 1981, 68:432-437

48. Schwartz HJ: Elevated serum tryptase in exercise-induced anaphylaxis. $J$ Allergy Clin Immunol 1995, 95:917-919.

49. Miller CWT, Guha B, Krishnaswamy G: Exercise-induced anaphylaxis: a serious but preventable disease. Phys Sportmed 2008, 36:87-94.

50. Sheffer AL, Soter N, McFadden ER, Austen KF: Exercise-induced anaphylaxis: a distinct form of physical allergy. J Allergy Clin Immunol 1983, 71:311-316.

51. Nichols AW: Exercise-induced anaphylaxis and urticaria. Med Sci Sports Med 1992, 11:303-312.

52. Robson-Ansley P, Toit GD: Pathophysiology, diagnosis and management of exercise-induced anaphylaxis. Curr Opin Allergy Clin Immunol 2010, 10:312-317.

53. Katsunuma $T$, likura $Y$, Akasawa A, Iwasaki A, Hashimoto K, Akimoto K. Wheat-dependent exercise-induced anaphylaxis: inhibition by sodium bicarbonate. Ann Allergy 1992, 68:184-188.

54. Hultman E, Sahlin K: Acid-base balance during exercise. Exerc Sport Sci Rev 1980, 8:41-128.

55. Victor RG, Bertocci LA, Pryor SL, Nunnally RL: Sympathetic nerve discharge is coupled to muscle cell $\mathrm{pH}$ during exercise in humans. J Clin Invest 1988, 82:1301-1305.

56. Saeki K, Endo K, Yamasaki H: Histamine release by inorganic cations from mast cell granules isolated by different procedures. Jpn J Pharmacol 1972 22:27-32.

57. Matsuo H, Morimoto K, Akaki T, Kaneko S, Kusatake K, Kuroda T, Niihara H, Hide M, Morita E: Exercise and aspirin increase levels of circulating gliadin peptides in patients with wheat-dependent exercise-induced anaphylaxis. Clin Exp Allergy 2005, 35:461-466.

58. Pals KL, Chang RT, Ryan AJ, Gisolfi CV: Effect of running intensity on intestinal permeability. J Appl Physiol 1997, 82:571-576. 
59. Schwartz LB, Irani AM, Roller K, Castells MC, Schechter NM: Quantitation of histamine, tryptase, and chymase in dispersed human T and TC mast cells. J Immunol 1987, 138:2611-2615.

60. Welle M: Development, significance, and heterogeneity of mast cells with particular regard to the mast cell-specific proteases chymase and tryptase. J Leukoc Biol 1997, 61:233-245.

61. Matsuo H, Morita E, Tatham AS, Morimoto K, Horikawa T, Osuna H, Ikezawa Z, Kaneko S, Kohno K, Dekio S: Identification of the IgE-binding epitope in omega-5 gliadin, a major allergen in wheat-dependent exercise-induced anaphylaxis. J Biol Chem 2004, 279:12135-12140.

62. Palosuo K, Varjonen E, Nurkkala J, Kalkkinen N, Harvima R, Reunala T, Alenius $\mathrm{H}$ : Transglutaminase-mediated cross-linking of a peptic fraction of omega-5 gliadin enhances IgE reactivity in wheatdependent, exerciseinduced anaphylaxis. J Allergy Clin Immunol 2003, 111:1386-1392.

63. Barg W, Wolanczyk-Medrala A, Obojski A, Wytrychowski K, Panaszek B, Medrala W: Food-dependent exercise induced anaphylaxis: possible impact of increased basophil histamine releasability in hyperosmolar conditions. J Investig Allergol Clin Immunol 2008, 18:312-316.

64. Wolanczyk-Medrala A, Barg W, Gogolewski G, Panaszek B, Liebhart J, Litwa M, Medrala W: Influence of hyperosmotic conditions on basophil CD203C upregulation in patients with food dependent exercise-induced anaphylaxis. Ann Agric Environ Med 2009, 16:301-304.

65. Wong GKY, Krishna MT, Collins DM, Goddard S, Huissoon AP: Wheat dependent exercise induced anaphylaxis:is this an appropriate terminology? J Clin Pathol 2010, 63:814-817.

66. Loibl M, Schwarz S, Ring J, Halle M, Brockow K: Definition of an exercise intensity threshold in a challenge test to diagnose food-dependent exercise induced anaphylaxis. Allergy 2009, 64:1560-1561.

67. Hanakawa Y, Tohyama M, Shirakata Y, Murakami S, Hashimoto K: Fooddependent exercise-induced anaphylaxis:a case related to the amount of food allergen ingested. Br J Dermatol 1998, 138:898-900

68. du Toit GD: Food-dependent exercise-induced anaphylaxis in childhood Pediatr Allergy Immunol 2007, 18:455-463.

69. Castells MC, Horan RF, Sheer AL: Exercise-induced anaphylaxis. Curr Allergy Asthma Rep 2003, 3:15-21.

70. Oyefaras BL, Bahna SL: Delayed food-dependent, exercise-induced anaphylaxis. Allergy Asthma Proc 2007, 28:64-66.

71. Drouet M, Sabbah A, Le SJ, Bonneau JC, Gay G, Dubois-Gosnet C: Fatal anaphylaxis after eating wild boar meat in a patient with pork-cat syndrome. Allerg Immunol (Paris) 2001, 33:163-165.

72. Flannagan LM, Wolf BC: Sudden death associated with food and exercise. J Forensic Sci 2004, 49:543-545

73. Caffarelli C, Cavagni G, Giordano S, Terzi V, Perrone F: Reduced pulmonary function in multiple food-induced, exercise-related episodes of anaphylaxis. J Allergy Clin Immunol 1996, 98:762-765.

74. Caffarelli C, Coscia A, Ridolo E, Povesi Dascola C, Gelmetti C, Raggi V, Volta E, Vanelli M, Dall'Aglio PP: Parents' estimate of food allergy prevalence and management in Italian school-aged children. Pediatr Int 2011, 53:505-510.

75. Caffarelli C, Cataldi R, Giordano S, Cavagni G: Anaphylaxis induced by exercise and related to multiple food intake. Allergy Asthma Proc 1997, $18: 245-248$

76. Caffarelli C, Ricò S, Rinaldi L, Povesi Dascola C, Terzi C, Bernasconi S: Blood pressure monitoring in children undergoing food challenge: relationship with anaphylaxis. Ann Allergy Asthma Immunol 2012, 108:285-286.

77. Milgrom H, Taussig LM: Keeping children with exercise-induced asthma active. Pediatrics 1999, 104:e38.

78. Bruce RA, Blackmon JR, Jones JW, Strait G: Exercise testing in adult normal subjects and cardiac patients. Pediatrics 1963, 32:742-756.

79. Morita E, Kunie K, Matsuo H: Food-dependent exercise-induced anaphylaxis. J Dermato/ Science 2007, 47:109-117.

80. Romano A, Di Fonso M, Giuffreda F, Quaratino D, Papa G, Palmieri V, Zeppilli $P$, Venuti A: Diagnostic work-up for food-dependent, exercise-induced anaphylaxis. Allergy 1995, 50:817-824

81. Fiocchi A, Mirri GP, Santini I, Bernardo L, Ottoboni F, Riva E: Exerciseinduced anaphylaxis after food contaminant ingestion in doubleblinded, placebo-controlled, food-exercise challenge. J Allergy Clin Immunol 1997, 100(3):424-425.

82. Horan RF, Sheffer AL, Briner WW: Physical Allergies. Med Sci Sport Exerc $1992,24: 845-848$
83. Mahler DA: Exercise-induced asthma. Med Sci Sports Exerc 1993 25:554-561.

84. Caffarelli C, Bacchini PL, Gruppi L, Bernasconi S: Exercise-induced bronchoconstriction in children with atopic eczema. Pediatr Allergy Immunol 2005, 16:655-661.

85. Hallstrand TS, Curtis JR, Koepsell TD, Martin DP, Schoene RB, Sullivan SD, Yorioka GN, Aitken ML: Effectivenesss of screening examinations to detect unrecognized exercise-induced bronchoconstrinction. J Paediatrics 2002, 141:343-349.

86. Sugimura $T$, Tananari $Y$, Ozaki $Y$, Maeno $Y$, Ito $S$, Yoshimoto $Y$, Kawano K, Tanaka S: Effect of sodium cromoglycate in 2 children with fooddependent exercise-induced anaphylaxis (FDEIA). Clin Pediatr 2009, 48(9):945-950.

87. Benhamou AH, Vanini G, Lantin JP, Eigenmann PA: Antihistamine and sodium cromoglycate medication for food cold water exercise-induced anaphylaxis. Allergy 2007, 62:1471-1472.

88. Choi JH, Lee HB, Ahn IS, Parck CW, Lee CH: Wheat-dependent, exerciseinduced anaphylaxis: a successful case of prevention with ketotifene. Dermatol 2009, 21(2):203-205.

89. Peroni DG, Piacentini GL, Piazza M: Combined cetirizine-montelukast preventive treatment for food-dependent exercise-induced anaphylaxis. Ann Allergy Asthma Immunol 2010, 104:272-273.

90. Pumphrey RSH: Fatal posture in anaphylactic shock. J Allergy Clin Immunol 2003, 112(2):451-452.

doi:10.1186/1824-7288-38-43

Cite this article as: Povesi Dascola and Caffarelli: Exercise-induced anaphylaxis: A clinical view. Italian Journal of Pediatrics 2012 38:43.

\section{Submit your next manuscript to BioMed Central and take full advantage of:}

- Convenient online submission

- Thorough peer review

- No space constraints or color figure charges

- Immediate publication on acceptance

- Inclusion in PubMed, CAS, Scopus and Google Scholar

- Research which is freely available for redistribution 